\title{
Adverse Events Following Infusion of T Cells for Adoptive Immunotherapy: A 10 Year Experience
}

\author{
Conrad Russell Cruz, Patrick J. Hanley, Hao Liu, Vicky Torrano, Yu-Feng Lin, James A. \\ Arce, Stephen Gottschalk, Barbara Savoldo, Gianpietro Dotti, Chrystal U. Louis, Ann M. \\ Leen, Adrian P. Gee, Cliona M. Rooney, Malcolm K. Brenner, Catherine M. Bollard, and Helen \\ E. Heslop \\ Center for Cell and Gene Therapy, Baylor College of Medicine, The Methodist Hospital, Texas \\ Children's Hospital, Houston TX USA
}

\begin{abstract}
Background-The FDA currently recommends at least 4 hours of recipient monitoring to detect early infusion reactions; recent catastrophic reactions to "first in man" biological agents have emphasized the importance of this rule for initial studies of new products. The value of such monitoring for better established agents is less obvious.
\end{abstract}

Methods-We therefore reviewed infusion-related adverse events (AEs) following administration of ex-vivo expanded T cell products (antigen specific CTLs, allodepleted T cells and genetically modified T cells) on Investigational New Drug (IND) studies in our center.

Results-From 1998 to 2008, we infused 381 T cell products to 180 recipients, enrolled on 18 studies, receiving $\mathrm{T}$ cells targeting malignancies or post-transplant viral infections. There were no Grade 3-4 infusion reactions during initial monitoring or 24 hour follow-up. Twenty four mild (grade 1-2) adverse events (AEs) occurred in 21 infusions either during or immediately following infusion (up to 6 hours), most commonly nausea and vomiting (10/24; 41.6\%), likely due to the DMSO cryoprotectant, and hypotension (20.8\%), attributable to diphenhydramine pre-medication. 22 additional non-severe events were reported within 24 hours of infusion, most commonly culture negative fever, chills and nausea. Increased risk of adverse effects was associated with age (IRR 0.98; 95\% CI 0.96-1.00; $\mathrm{p}=0.05$ ), while an increase risk of immediate infusion-related events was higher in patients reporting allergies (IRR 2.72; 95\% CI 1.00-7.40; $\mathrm{p}=0.05$ ); sex, disease type or T cell source (allogeneic or autologous) had no effect on frequency of adverse events.

Discussion-Hence infusion of $\mathrm{T}$ cells is safe in the outpatient setting and associated with no severe reactions, so that monitoring for one hour after infusion is likely sufficient. As many of the AEs were attributable to diphenhydramine premedication, a lower dose $(0.25 \mathrm{mg} / \mathrm{kg})$ should be selected.

\section{Keywords}

T cells; Cytotoxic T Lymphocytes; Epstein-Barr virus; Infusion reaction; Adverse events

\section{INTRODUCTION}

T cell therapies can benefit a range of disorders including cancer, viral infections, invasive fungal disease, and autoimmune and allergic disorders(1-9). The number of trials exploring

Correspondence: Dr. Helen Heslop, Center for Cell and Gene Therapy, 1102 Bates St, Suite 1620, Houston, TX 77030, Phone: 832824 4662, FAX: 832825 4668, hheslop@bcm.edu. 
this approach has increased substantially over the past decade and the clinical trials database currently lists 180 approved T cell immunotherapy protocols in 30 countries around the world (10). While clinical toxicities and adverse event profiles have been reported for other cell-based infusion products $(11 ; 12)$, there has been no comprehensive evaluation of infusion reactions after administration of ex-vivo manipulated $\mathrm{T}$ cells. Infusion of $\mathrm{T}$ cells could mediate a panoply of unintended effects, including fever and nonspecific constitutional symptoms, as a consequence of inflammatory mediator release or cytokine secretion, by transmission of infectious agents or following acute lung injury due to their entrapment in the pulmonary vasculature (13).

The FDA currently recommends at least 4 hours of recipient monitoring following administration of ex-vivo expanded T cells and two recent severe adverse events (AEs) after "first in man" biological agents have emphasized the importance of this rule for initial clinical studies using new products. In the first case, a patient received T cells modified to express a chimeric antigen receptor (CAR) specific to the B cell tumor antigen CD19 that also contained a co-stimulatory moiety (CD28). The patient was lymphodepleted with cyclophosphamide prior to the infusion. Within 48 hours the patient developed fever, hypotension, dyspnea, and renal failure, with negative blood cultures, and progressed to a fatal outcome (14). A second patient received $T$ cells transduced with a chimeric antigen receptor targeting HER2/neu containing both the CD28 and 4-1BB costimulatory domains(15). Within 4 hours of infusion, this patient developed rapidly progressive respiratory distress requiring ventilation(15) and subsequently died. Although these events were rare, they emphasize why a high level of monitoring is required for any first in man study; however the relevance for more established $\mathrm{T}$ cell infusion products is not known. We therefore retrospectively studied the incidence and severity of immediate and early adverse events occurring in subjects enrolled on 18 different IND studies of ex vivo manipulated $\mathrm{T}$ cell cells over a 10 year period at our institution.

\section{METHODS}

\section{Patient Details}

We reviewed the charts, infusion records, and adverse event reports of 180 patients who received 381 infusions of ex-vivo expanded T cells on IND studies at the Center for Cell and Gene Therapy at Baylor College of Medicine, The Methodist Hospital and Texas Children's Hospital in Houston, Texas from January 1, 1998 to November 20, 2008. Included in this study were patients who received antigen-specific cytotoxic T cells, allodepleted T cells, or genetically modified $\mathrm{T}$ cells, on $18 \mathrm{FDA}$-approved investigational new drug studies. The infused T cells targeted malignancies or viral infections after hemopoietic stem cell transplant (HSCT). Cell doses were protocol specific and ranged from $10^{4} / \mathrm{kg}$ up to $2 \times 10^{8} / \mathrm{m}^{2}$. Patients were premedicated with intravenous diphenhydramine $(0.5-1 \mathrm{mg} / \mathrm{kg}$, with a maximum dose of $50 \mathrm{mg}$ ) and Tylenol (10mg/kg up to a maximum dose of $625 \mathrm{mg})$ prior to infusion. All cellular products were cryopreserved using 10\% DMSO and administered intravenously over 1-15 minutes immediately after thawing. The types of cellular products are summarized in Table 1.

All patients were treated on IRB approved protocols conducted under INDs after approval by the FDA. If $T$ cells were genetically modified or if they were stimulated by antigen presenting cells that were genetically modified the studies were also reviewed by the Recombinant DNA Advisory Committee of the National Institutes of Health and the Institutional Biosafety Committee. This collated analysis, combining data on infusion safety from all 18 studies was also approved by the IRB at Baylor College of Medicine. Adverse events were collected and graded on case report forms using NCI common toxicity criteria (version 2 or 3 depending on when the study was initiated). 
Outcome data from some of these studies have been reported (16-26) but a detailed analysis of infusion-related adverse events has not been previously presented.

\section{Statistical methods}

We initially used descriptive statistics (mean, standard deviation, median and range) to analyze the data. All patients who received T-cell infusions were included in the analysis. Adverse event data were summarized in the form of tables. Incidence tables were generated to summarize incidence of patients reporting at least one episode of each specific adverse event and incidence of serious adverse events. The total number of episodes for each event reported, the grade and attribution to study therapy of each episode reported were summarized. The incidence of adverse events was also listed by age group, presence of an allergy and source of $\mathrm{T}$ cells, and compared by Fisher's exact test. The association of the incidence of AE with the type of cells, gender, age at infusion and presence of allergy was then further analyzed by the Poisson regression model using the generalized estimation equation (GEE) to account for the correlation of $\mathrm{AE}$ within subjects, and we report estimates of the association and the robust $95 \%$ confidence intervals. All p-values are 2 -sided, with $\mathrm{P}<0.05$ considered statistically significant. All statistical analyses used R and STATA 9.0 software packages.

\section{RESULTS}

\section{Patient Characteristics}

A total of $381 \mathrm{~T}$ cell products were given to 180 patients (some studies infused more than two products (23) or had more than one infusion) during the ten year period between 1998 to 2008. Patient characteristics are summarized in Table 2. The types of $\mathrm{T}$ cell products infused are summarized in Table 3.

\section{Adverse Events Resulting from the Infusion are Non-Severe}

Twenty four grade 1-2 adverse events (AEs) occurred in 21 infusions of 22 ex vivo expanded $\mathrm{T}$ cell products (one patient was enrolled on a study where two products were administered), giving an incidence of $6.55 \%$, either during infusion or the immediate post-infusion monitoring period (which lasted between $1-6$ hours). Figure 1 summarizes the observed events. Figure 2 enumerates an additional 22 events (incidence of reported or observed adverse events occurring in the 24 hour window following $\mathrm{T}$ cell infusion). Again, no severe adverse events that were related to the $T$ cell products were noted. Overall, we observed a total of 46 immediate (within 24 hours) non-severe adverse events $(12.56 \%)$ and no severe adverse events following the infusion of ex vivo manipulated $\mathrm{T}$ cells. The most common adverse events were nausea/ vomiting and hypotension.

\section{The Majority of Adverse Events are Related to DMSO or Diphenhydramine}

All infusions consisted of T cell products suspended in media containing 10\% DMSO as a cryoprotectant and the cells were not washed prior to infusions. Subjects received the infusions after premedication with diphenhydramine and acetaminophen, except when contraindicated by the presence of allergies or by concomitant medications that would produce unwanted interactions. As seen in Figure 3, most of the immediate adverse events noted were attributed to DMSO (e.g. nausea/vomiting, taste disturbance) or diphenhydramine (e.g. hypotension, transient hypoxia resulting from sedation).

\section{Relationship of Adverse Events to Other factors}

For analysis, adverse events (AEs) were defined as an event grade 1 or higher, possibly, probably, or definitely related to the $\mathrm{T}$ cell infusion. Because all adverse events were nonsevere, no attempt was made to distinguish AE grades in the analysis. 
Adverse events were first summarized by infusion episode. Fisher's exact analysis of all T cell product infusions grouped by patient age, patient ethnicity, or cell source did not reveal any associations with increased risks for adverse events. The very young and the very old were no more susceptible to untoward side effects from T cell infusions (Table 4a). Neither the patient's ethnicity (Table $4 \mathrm{~b}$ ) nor increasing antigenic mismatch between donor and recipient cells (Table 4c \& 4d) contributed to a higher incidence of AEs. T cells from both allogeneic and autologous sources resulted in similar rates of adverse events following infusions (Table 4c), and allogeneic cells that were mismatched at more than 2 antigens are no more associated with adverse events than donor $\mathrm{T}$ cells matched at 5/6 and 6/6 HLA loci. (Table 4d).

Analysis by infusion episodes, however, is not very comprehensive, as AE within a subject are not statistically independent. We thus performed more rigorous data analysis of the data by individual subject. Since the number of AE events from each individual should follow a Poisson distribution, we used a Poisson regression model with a generalized estimating equation (GEE) for correlated count data. We estimated the incidence rate (IR) per subject, and by covariates and in this multivariate Poisson regression model we compared: autologous vs allogeneic stem cell source of $\mathrm{T}$ cells, patient gender, age at infusion, and the presence of allergies. We also fitted the Poisson regression model to the level of antigen mismatch for recipients of allogeneic $\mathrm{T}$ cells. Stratifying adverse event data by incidence rates per patient results in significantly lower incidences seen as patient age increases. Immediate adverse event rates are also increased in patients with documented allergies. (IRR $=$ incidence rate ratio, $\mathrm{AE}=$ adverse event) In our analysis of patients with allergies, we classified patients whose allergy status is undocumented within the allergy group, to make for a more conservative estimate of the effects of allergies and to avoid dropping any patients from our calculations. By this approach we found a significant effect of older age on the probability of both immediate and total adverse events. The presence of allergies also predisposed patients to develop immediate infusion reactions. (Table 5).

\section{DISCUSSION}

Most complex biological products such as ex-vivo expanded T cells are prepared following multi-step procedures - including cell activation, ex vivo expansion using complex media, serum and cytokines, and genetic modification, all of which may increase the risk for subsequent infusion reactions from infection, contamination or hypersensitivity (27). Several studies have previously looked at the safety profile of unmanipulated or minimally manipulated cellular therapies $(11 ; 12)$, but our study was aimed at evaluating the consequences of infusing ex-vivo expanded T cells. Our intent was to provide guidance for immediate safety monitoring after administration of these cellular products. We identified an overall adverse event (AE) incidence rate of $17.3 \%$, and none of these AE's were severe. This excellent safety record is similar to preliminary experience with other cell-based therapies (28) Of note, the majority of AEs in our analysis could be attributed to either the cryoprotectant (DMSO) or the diphenhydramine used as premedication rather than to the $\mathrm{T}$ cells themselves.

Of the adverse events observed, only mild immune/inflammatory responses (constitutional symptoms, mild fever, chills) reported on 10 occasions within 24 hours of $\mathrm{T}$ cell infusion are likely mediated by the ex vivo generated $\mathrm{T}$ cell products; a similar rate of such symptoms have been reported in studies of other cell products (29). Since we found an increased risk of infusion reactions in recipients with documented allergies, we recommend careful monitoring of those patients who report such predispositions. We observed no differences in adverse event rates if patients are grouped according to cell source used for infusion.

DMSO is a commonly used cryoprotectant, and a variety of methods have been proposed to minimize the adverse effects of this agent. Washing cells prior to infusion is effective, but 
introduces additional variables into analysis of product functionality that we believed unjustified by the low rate and severity of infusion reactions. Fractionated cell infusions (30) and the use of strawberry flavored lollipops (31) have been shown to decrease the incidence of DMSO-related clinical effects.

The patients in this series received relatively low infusion volumes $(0.7 \mathrm{~mL}$ to $58 \mathrm{~mL})$ and $\mathrm{T}$ cell numbers $\left(3 \times 10^{5} / \mathrm{kg}\right.$ to $2 \times 10^{8}$ cells $\left./ \mathrm{m}^{2}\right)$. While larger quantities, or first in man products may have an entirely different safety profile due, for example, to pulmonary vascular congestion or cytokine storms (14), our experience with these more established, smaller scale infusions, clearly shows immediate safety.

Hence, we propose that one hour monitoring post-infusion, with clear instructions to the patients to report any adverse events they see before the next clinic visit, should be sufficient to maintain this excellent safety record. Indeed, reduction of the dosage of diphenhydramine may reduce adverse events, such as mild hypotension, still further.

\section{Acknowledgments}

This work was supported by grants RO1CA061384, PO1 CA94237, P50CA126752 and U54HL081007 from the National Institutes of Health and a SCOR from the Leukemia and Lymphoma Society. We wish to thank all the clinicians involved in care of these patients, the staff in the GMP facilities who manufactured cells and all the research staff who collected data.

\section{Reference List}

1. Rosenberg SA, Restifo NP, Yang JC, Morgan RA, Dudley ME. Adoptive cell transfer: a clinical path to effective cancer immunotherapy. Nat Rev Cancer 2008 Apr;8(4):299-308. [PubMed: 18354418]

2. Disis ML, Bernhard H, Jaffee EM. Use of tumour-responsive T cells as cancer treatment. Lancet 2009 Feb 21;373(9664):673-83. [PubMed: 19231634]

3. June CH. Adoptive T cell therapy for cancer in the clinic. J Clin Invest 2007 Jun;117(6):1466-76. [PubMed: 17549249]

4. Leen AM, Rooney CM, Foster AE. Improving T cell therapy for cancer. Annu Rev Immunol 2007;25:243-65. [PubMed: 17129181]

5. Fujita Y, Rooney CM, Heslop HE. Adoptive cellular immunotherapy for viral diseases. Bone Marrow Transplant 2008 Jan;41(2):193-8. [PubMed: 17982497]

6. Beck O, Topp MS, Koehl U, Roilides E, Simitsopoulou M, Hanisch M, et al. Generation of highly purified and functionally active human TH1 cells against Aspergillus fumigatus. Blood 2006 Mar 15;107(6):2562-9. [PubMed: 16322466]

7. Nicolson KS, Wraith DC. Natural and induced regulatory T cells: targets for immunotherapy of autoimmune disease and allergy. Inflamm Allergy Drug Targets 2006 Sep;5(3):141-8. [PubMed: 16918477]

8. Leen AM, Heslop HE. Cytotoxic T lymphocytes as immune-therapy in haematological practice. Br J Haematol 2008 Oct;143(2):169-79. [PubMed: 18691164]

9. Falkenburg JH, Heslop HE, Barrett AJ. T cell therapy in allogeneic stem cell transplantation. Biol Blood Marrow Transplant 2008 Jan;14(1 Suppl 1):136-41. [PubMed: 18162234]

10. National Institutes of Health. Clinical Trials.Gov. Jun 5. 9 A.D.Available from: URL: http://www.clinicaltrials.gov/ct2/results?term=t+cell+immunotherapy

11. Alessandrino P, Bernasconi P, Caldera D, Colombo A, Bonfichi M, Malcovati L, et al. Adverse events occurring during bone marrow or peripheral blood progenitor cell infusion: analysis of 126 cases. Bone Marrow Transplant 1999 Mar;23(6):533-7. [PubMed: 10217182]

12. Cordoba R, Arrieta R, Kerguelen A, Hernandez-Navarro F. The occurrence of adverse events during the infusion of autologous peripheral blood stem cells is related to the number of granulocytes in the leukapheresis product. Bone Marrow Transplant 2007 Dec;40(11):1063-7. [PubMed: 17906706] 
13. Food and Drug Administration. Proposed Approach to Regulation of Cellular and Tissue-Based Products. 1997 February 28;

14. Brentjens RJ, Riviere I, Hollyman D, Taylor C, Nikhamin Y, Stefanski J, et al. Unexpected Toxicity of Cyclophosphamide Followed by Adoptively Transferred CD19-Targeted T Cells in a Patient with Bulky CLL. Molecular Therapy 2009;17(Suppl 1):S157.

15. Minutes of the December 1st 2009 RAC meeting. 2009. http://obaodnihgov/rdna_rac/rac_meetingshtml

16. Savoldo B, Huls MH, Liu Z, Okamura T, Volk HD, Reinke P, et al. Autologous Epstein-Barr virus (EBV)-specific cytotoxic T cells for the treatment of persistent active EBV infection. Blood 2002 Dec 1;100(12):4059-66. [PubMed: 12393655]

17. Bollard CM, Aguilar L, Straathof KC, Gahn B, Huls MH, Rousseau A, et al. Cytotoxic T Lymphocyte Therapy for Epstein-Barr Virus+ Hodgkin's Disease. J Exp Med 2004 Dec 20;200(12):1623-33. [PubMed: 15611290]

18. Straathof KC, Bollard CM, Popat U, Huls MH, Lopez T, Morriss MC, et al. Treatment of Nasopharyngeal Carcinoma with Epstein-Barr Virus-specific T Lymphocytes. Blood 2005 Mar 1;105:1898-904. [PubMed: 15542583]

19. Amrolia PJ, Muccioli-Casadei G, Huls H, Adams S, Durett A, Gee A, et al. Adoptive immunotherapy with allodepleted donor T-cells improves immune reconstitution after haploidentical stem cell transplantation. Blood 2006 Sep 15;108(6):1797-808. [PubMed: 16741253]

20. Leen AM, Myers GD, Sili U, Huls MH, Weiss H, Leung KS, et al. Monoculture-derived T lymphocytes specific for multiple viruses expand and produce clinically relevant effects in immunocompromised individuals. Nat Med 2006 Nov;12(10):1160-6. [PubMed: 16998485]

21. Savoldo B, Goss JA, Hammer MM, Zhang L, Lopez T, Gee AP, et al. Treatment of solid organ transplant recipients with autologous Epstein Barr virus-specific cytotoxic T lymphocytes (CTLs). Blood 2006 Nov 1;108(9):2942-9. [PubMed: 16835376]

22. Bollard CM, Gottschalk S, Leen AM, Weiss H, Straathof KC, Carrum G, et al. Complete responses of relapsed lymphoma following genetic modification of tumor-antigen presenting cells and Tlymphocyte transfer. Blood 2007 Oct 15;110(8):2838-45. [PubMed: 17609424]

23. Pule MA, Savoldo B, Myers GD, Rossig C, Russell HV, Dotti G, et al. Virus-specific T cells engineered to coexpress tumor-specific receptors: persistence and antitumor activity in individuals with neuroblastoma. Nat Med 2008 Nov;14(11):1264-70. [PubMed: 18978797]

24. Louis CU, Straathof K, Bollard CM, Gerken C, Huls MH, Gresik MV, et al. Enhancing the in vivo expansion of adoptively transferred EBV-specific CTL with lymphodepleting CD45 monoclonal antibodies in NPC patients. Blood 2009 Mar 12;113(11):2442-50. [PubMed: 18971421]

25. Leen AM, Christin A, Myers GD, Liu H, Cruz CR, Hanley PJ, et al. Cytotoxic T lymphocyte therapy with donor $\mathrm{T}$ cells prevents and treats adenovirus and Epstein-Barr virus infections after haploidentical and matched unrelated stem cell transplant. Blood. 2009 Aug 21;

26. Heslop HE, Slobod KS, Pule MA, Hale GA, Rousseau A, Smith CA, et al. Long term outcome of EBV specific T-cell infusions to prevent or treat EBV-related lymphoproliferative disease in transplant recipients. Blood. 2009 Oct 30;

27. Burger SR. Current regulatory issues in cell and tissue therapy. Cytotherapy 2003;5(4):289-98. [PubMed: 12944234]

28. Gastineau DA. Will regulation be the death of cell therapy in the United States? Bone Marrow Transplant 2004 Apr;33(8):777-80. [PubMed: 14968138]

29. Higano CS, Schellhammer PF, Small EJ, Burch PA, Nemunaitis J, Yuh L, et al. Integrated data from 2 randomized, double-blind, placebo-controlled, phase 3 trials of active cellular immunotherapy with sipuleucel-T in advanced prostate cancer. Cancer. 2009 Jun 17;

30. Martino M, Morabito F, Messina G, Irrera G, Pucci G, Iacopino P. Fractionated infusions of cryopreserved stem cells may prevent DMSO-induced major cardiac complications in graft recipients. Haematologica 1996 Jan;81(1):59-61. [PubMed: 8900855]

31. Ozdemir E, Akgedik K, Akdogan S, Kansu E. The lollipop with strawberry aroma may be promising in reduction of infusion-related nausea and vomiting during the infusion of cryopreserved peripheral blood stem cells. Biol Blood Marrow Transplant 2008 Dec;14(12):1425-8. [PubMed: 19041066] 


\section{Abbreviations}

$\begin{array}{ll}\text { AEs } & \text { Adverse events (AEs) } \\ \text { CAR } & \text { Chimeric antigen receptor } \\ \text { CTLs } & \text { Cytotoxic T Lymphocytes } \\ \text { DMSO } & \text { Dimethyl sulfoxide } \\ \text { DNA } & \text { Deoxyribonucleic acid } \\ \text { EBV } & \text { Epstein-Barr virus } \\ \text { FDA } & \text { Food and Drug Administration } \\ \text { GEE } & \text { Generalized Estimation Equation } \\ \text { HLA } & \text { Human Leukocyte Antigen } \\ \text { HSCT } & \text { Hemopoietic Stem Cell Transplant } \\ \text { IND } & \text { Investigational New Drug } \\ \text { IRB } & \text { Institutional Review Board }\end{array}$




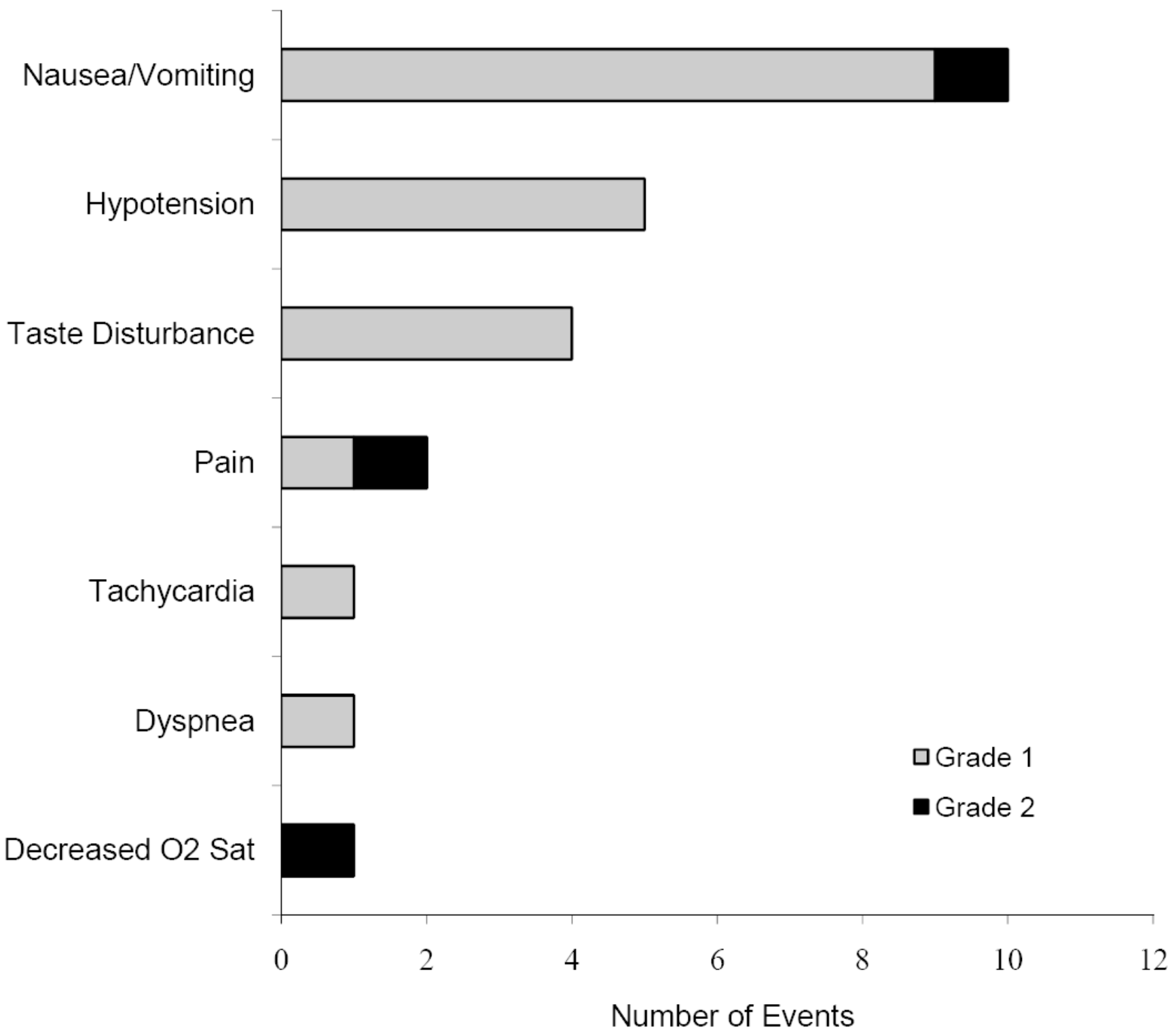

Figure 1. Adverse Events During T Cell Infusion/Post-Infusion Monitoring

Twenty four adverse reactions during infusion or the immediate post-infusion monitoring period amount to an incidence of $6.5 \%$ adverse events in 366 infusions of $381 \mathrm{~T}$ cell products. Two grade 3 reactions, 2 grade 2 reactions, and 2 grade 1 reactions were also reported but were considered unrelated to the $\mathrm{T}$ cell products. All adverse events that were possibly/definitely related to the $\mathrm{T}$ cell infusion were non severe (grade 1-2). Adding the adverse events related to $\mathrm{T}$ cell infusion reported within 24 hours results in an incidence of $12.5 \%$. 


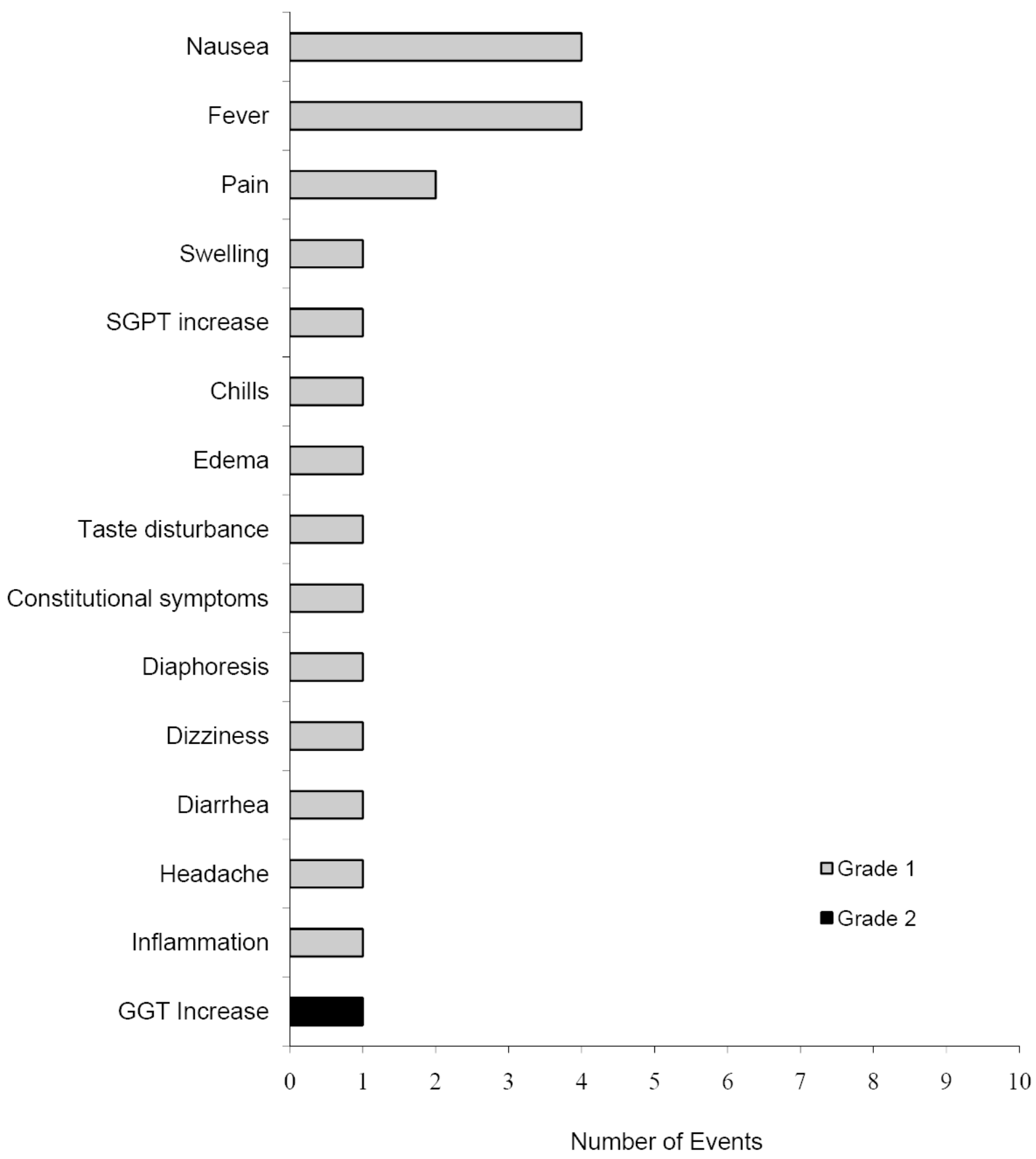

Figure 2. Adverse Events Reported Within 24 Hours

An additional 266 adverse events were reported within a day after infusion. A total of twenty two events possibly or definitely related to the ex vivo manipulated $T$ cell product are listed here (all of which are non-severe/grade 1-2). Both the frequency of each adverse event and the severity of the reaction are noted. 


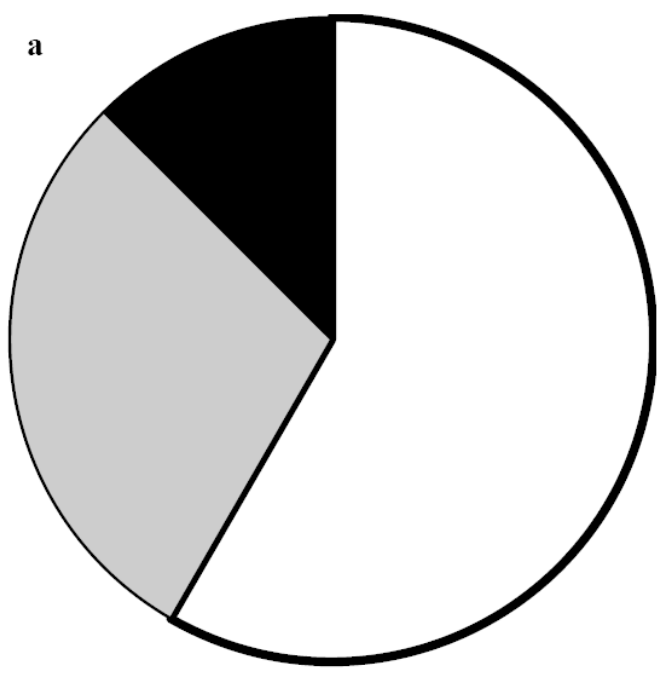

口Likely Due to DMSO

口Likely Due to Diphenhydramine mother

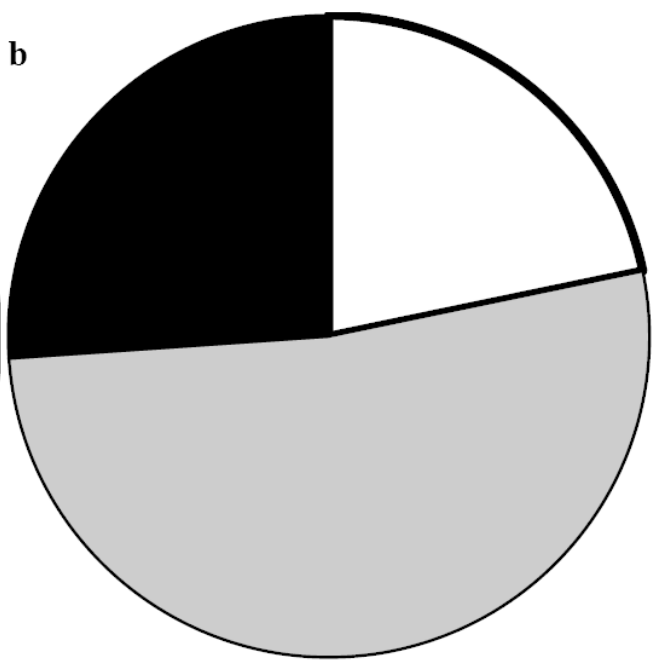

口Likely Due to DMSO

口Possibly Due to T Cell Product -Others

Figure 3. Adverse Events Attributable to DMSO or Diphenhydramine

Most of the (a) immediate adverse events seen during infusion and the post-infusion period are attributable to either DMSO or diphenhydramine. There were an additional five adverse events attributable to DMSO seen or reported (b) within 24 hours of infusion, with most events at this time period conceivably resulting from a mild inflammatory process mediated by the $\mathrm{T}$ cell products. None of the adverse events were severe enough to be a cause of concern. 
Table 1

Summary of Studies

\begin{tabular}{|c|c|c|c|}
\hline Study Name & T Cell Product & Dose Range (cells/m²) & Indication \\
\hline ANGEL NCT00058617 & Autologous EBV-specific CTL & $2 \times 10^{7}-2 \times 10^{8}$ & $\begin{array}{l}\text { Relapsed EBV-positive } \\
\text { Hodgkin's disease lymphoma } \\
\text { (17) }\end{array}$ \\
\hline ANGELA NCT00058773 & Autologous EBV-specific CTL & $2 \times 10^{7}-2 \times 10^{8}$ & $\begin{array}{l}\text { EBV-positive Hodgkin's } \\
\text { disease post autograft (17) }\end{array}$ \\
\hline SCAEBV NCT00608608 & Autologous EBV-specific CTL & $1 \times 10^{7}-1 \times 10^{8}$ & $\begin{array}{l}\text { Severe chronic active EBV } \\
\text { infection (16) }\end{array}$ \\
\hline EUCLID NCT00058604 & Autologous EBV-specific CTL & $2 \times 10^{7}-1 \times 10^{8}$ & $\begin{array}{l}\text { Prevention and treatment of } \\
\text { EBV lymphoma following solid } \\
\text { organ transplantation (21) }\end{array}$ \\
\hline NPC & Autologous EBV-specific CTL & $2 \times 10^{7}-2 \times 10^{8}$ & Nasopharyngeal carcinoma (18) \\
\hline CLANC NCT00608257 & Autologous EBV-specific CTL & $2 \times 10^{7}-1 \times 10^{8}$ & $\begin{array}{l}\text { EBV-positive nasopharyngeal } \\
\text { cancer after lymphodepletion } \\
\text { (24) }\end{array}$ \\
\hline NATELLA NCT00682864 & Autologous LMP1/LMP2 specific CTL & $2 \times 10^{7}-2 \times 10^{8}$ & Nasopharyngeal carcinoma \\
\hline NESTLES NCT00085930 & $\begin{array}{l}\text { Autologous 14g2a-zeta-CAR-transduced CTL and } \\
\text { 14g2a-zeta-CAR-transduced EBV-specific CTL }\end{array}$ & $2 \times 10^{7}$ & High-risk Neuroblastoma (23) \\
\hline ALASCER NCT00070226 & Autologous or donor derived LMP2a-specific CTL & $2 \times 10^{7}-1 \times 10^{8}$ & $\begin{array}{l}\text { EBV-positive lymphoma, } \\
\text { Hodgkin's Disease } \\
\text { lymphoepithelioma, or severe } \\
\text { chronic EBV (22) }\end{array}$ \\
\hline ALCI NCT00671164 & $\begin{array}{l}\text { Autologous or donor-derived LMP1/LMP2 specific } \\
\text { CTL }\end{array}$ & $2 \times 10^{7}-1 \times 10^{8}$ & $\begin{array}{l}\text { EBV-positive lymphoma, } \\
\text { lymphoepithelioma, or severe } \\
\text { chronic EBV }\end{array}$ \\
\hline ACDAL NCT00082225 & Autologous or donor-derived LMP2a-specific CTL & $2 \times 10^{7}-1 \times 10^{8}$ & $\begin{array}{l}\text { EBV-positive Hodgkin's } \\
\text { disease or non-Hodgkin's } \\
\text { lymphoma after } \\
\text { lymphodepletion }\end{array}$ \\
\hline ETNA NCT00058604 & Donor-derived EBV-specific CTL & $2 \times 10^{7}-1.2 \times 10^{8}$ & $\begin{array}{l}\text { Immune reconstitution in } \\
\text { allogeneic/mismatch HSCT } \\
\text { recipients (26) }\end{array}$ \\
\hline LYPTAIST NCT00111033 & Donor-derived adenovirus/EBV-specific CTL & $5 \times 10^{6}-1.35 \times 10^{8}$ & $\begin{array}{l}\text { Adenovirus and EBV infection } \\
\text { post allogeneic HSCT (25) }\end{array}$ \\
\hline VICTA NCT00078533 & Donor-derived CMV/adenovirus/EBV-specific CTL & $1 \times 10^{7}-1 \times 10^{8}$ & $\begin{array}{l}\text { Prophylaxis of CMV, } \\
\text { adenovirus and EBV infection } \\
\text { post allogeneic HSCT (20) }\end{array}$ \\
\hline CHALLAH NCT00711035 & $\begin{array}{l}\text { Third party allogeneic adenovirus/EBV/CMV- } \\
\text { specific CTL }\end{array}$ & $2 \times 10^{7}$ & $\begin{array}{l}\text { Third party CTLs for persistent } \\
\text { reactivation/infection with } \\
\text { adenovirus/EBV/CMV after } \\
\text { HSCT }\end{array}$ \\
\hline RFT-DGA NCT00622297 & Donor-derived allodepleted $\mathrm{T}$ cells & $1 \times 10^{4}-5 \times 10^{6^{*}}$ & $\begin{array}{l}\text { Immune reconstitution post- } \\
\text { haploidentical stem cell } \\
\text { transplant (19) }\end{array}$ \\
\hline RAFAHS NCT00586274 & Donor-derived allodepleted $\mathrm{T}$ cells & $1 \times 10^{4^{*}}$ & $\begin{array}{l}\text { Immune reconstitution post- } \\
\text { haploidentical stem cell } \\
\text { transplant for Fanconi anemia } \\
\text { (19) }\end{array}$ \\
\hline HIMRFT NCT00586547 & Allodepleted T cells & $1 \times 10^{3}-1 \times 10^{4} *$ & $\begin{array}{l}\text { Immune reconstitution post- } \\
\text { reduced intensity haploidentical } \\
\text { stem cell transplant (19) }\end{array}$ \\
\hline
\end{tabular}




\section{Table 2}

\section{Patient Characteristics}

\begin{tabular}{|c|c|}
\hline Characteristic & T cell Recipients \\
\hline Age at Infusion & $\begin{array}{l}\text { range } 9 \text { mo. to } 80.4 \mathrm{y} \\
\text { mean } 26.6 \mathrm{y} \\
\text { median } 18.5 \mathrm{y}\end{array}$ \\
\hline Male:female & 109:71 \\
\hline \multicolumn{2}{|l|}{ Ethnicity } \\
\hline White & 86 \\
\hline Hispanic & 41 \\
\hline Asian & 25 \\
\hline Black & 20 \\
\hline Others & 8 \\
\hline \multicolumn{2}{|l|}{ Primary Diagnosis } \\
\hline Nasopharyngeal carcinoma & 42 \\
\hline Hodgkin's lymphoma & 28 \\
\hline AML & 18 \\
\hline Non-Hodgkin's lymphoma & 16 \\
\hline ALL & 15 \\
\hline Neuroblastoma & 14 \\
\hline Post-solid organ transplant & 11 \\
\hline Severe, chronic EBV infection & 10 \\
\hline Lymphoproliferative disorders & 5 \\
\hline Myelodysplastic syndrome & 4 \\
\hline Beta-thalassemia & 3 \\
\hline Hemophagocytic syndromes & 3 \\
\hline Aplastic anemia & 2 \\
\hline CML & 2 \\
\hline Multiple Myeloma & 2 \\
\hline SCID & 2 \\
\hline Fanconi's anemia & 1 \\
\hline Lymphoepithelioma & 1 \\
\hline Acute Biphenotypic Leukemia & 1 \\
\hline
\end{tabular}

Cytotherapy. Author manuscript; available in PMC 2011 October 1. 
Table 3

Types of Infusion

\begin{tabular}{l|l}
\hline Type of T cell Product & \\
Allogeneic & \\
Adenovirus/EBV/CMV-specific CTLs & 24 \\
Adenovirus/EBV-specific CTLs & 14 \\
EBV-specific CTLs & 13 \\
Allodepleted CTLs & 47 \\
LMP2a-specific CTLs & 14 \\
LMP1/LMP2a-specific CTLs & 4 \\
Autologous & \\
EBV-specific CTLs & 139 \\
CAR-transduced EBV-specific CTLs & 15 \\
CAR-transduced OKT3 blasts & 15 \\
LMP2a-specific CTLs & 44 \\
LMP1/LMP2a-specific CTLs & 52 \\
\hline
\end{tabular}


Table 4

Incidence of Adverse Events Analyzed by T Cell Infusion

\begin{tabular}{lll}
\multicolumn{2}{l}{ a. Adverse events subgrouped by age } \\
No. of AE & Age $<18$ & Age $>18$ \\
\hline 0 & 152 & 195 \\
& 92.12 & 90.28 \\
1 & 8 & 16 \\
& 4.85 & 7.41 \\
2 & 5 & 3 \\
& 3.03 & 1.39 \\
3 & 0 & 2 \\
& 0 & 0.93 \\
Total & 165 & 216 \\
Fisher's Exact & $\mathbf{0 . 3 6 0}$ &
\end{tabular}

\begin{tabular}{lll}
\hline \multicolumn{3}{l}{ b. Adverse events subgrouped by presence of allergies } \\
\hline No. of AE & No allergy & With allergy \\
\hline 0 & 190 & 157 \\
& 92.23 & 89.71 \\
1 & 10 & 14 \\
& 4.85 & 8 \\
2 & 5 & 3 \\
& 2.43 & 1.71 \\
3 & 1 & 1 \\
& 0.49 & 0.57 \\
Total & 206 & 175 \\
Fisher's Exact & $\mathbf{0 . 6 2 4}$ & \\
\hline
\end{tabular}

\begin{tabular}{lll}
\multicolumn{3}{l}{ c. Adverse events subgrouped by T cell source } \\
\hline No. of AE & Autologous & Allogeneic \\
\hline 0 & 241 & 106 \\
& 90.94 & 91.38 \\
1 & 17 & 7 \\
& 6.42 & 6.03 \\
2 & 5 & 3 \\
& 1.89 & 2.59 \\
3 & 2 & 0 \\
& 0.75 & 0.93 \\
Total & 265 & 116 \\
Fisher's Exact & $\mathbf{0 . 9 5 0}$ & \\
\hline
\end{tabular}

$\underline{\text { d. Adverse events in allogeneic } \mathrm{T} \text { cell products subgrouped by extent of antigenic mismatch }}$ No. of $\mathrm{AE}$ $4 / 6$ $5 / 6$ $6 / 6$ Unspecified 


\begin{tabular}{lllll}
\hline 0 & 50 & 6 & 39 & 11 \\
& 94.34 & 85.71 & 88.64 & 91.67 \\
1 & 1 & 1 & 4 & 1 \\
& 1.89 & 14.29 & 9.09 & 8.33 \\
2 & 2 & 0 & 1 & 0 \\
& 3.77 & 0 & 2.27 & 0 \\
Total & 53 & 7 & 44 & 12 \\
Fisher's Exact & $\mathbf{0 . 4 5 8}$ & & & \\
\hline
\end{tabular}




\section{Table 5}

Incidence of Adverse Events Analyzed Per Patient

\begin{tabular}{llll}
\hline & IRR & $95 \%$ Confidence Interval & p-value \\
Immediate AE & & & \\
Auto vs Allo & 0.27 & $0.07-1.11$ & 0.07 \\
Male vs Female & 0.59 & $0.23-1.52$ & 0.28 \\
Age at Infusion & 0.97 & $0.94-1.00$ & 0.05 \\
Allergy vs No Allergy & 2.72 & $1.00-7.40$ & 0.05 \\
AEs After 24 Hours & & & \\
Auto vs Allo & 1.32 & $0.34-5.05$ & 0.69 \\
Male vs Female & 0.49 & $0.19-1.27$ & 0.14 \\
Age at Infusion & 0.99 & $0.96-1.01$ & 0.27 \\
Allergy vs No Allergy & 0.77 & $0.31-1.87$ & 0.56 \\
Total AEs & & & \\
Auto vs Allo & 0.58 & $0.22-1.54$ & 0.28 \\
Male vs Female & 0.56 & $0.29-1.11$ & 0.1 \\
Age at Infusion & 0.98 & $0.96-1.00$ & 0.05 \\
Allergy vs No Allergy & 1.41 & $0.73-2.71$ & 0.31 \\
\hline
\end{tabular}

Cytotherapy. Author manuscript; available in PMC 2011 October 1. 